\title{
LIQUIDITY - PROFITABILITY TRADE-OFF ON THE EXAMPLE OF COMPANIES LISTED ON MAIN AND ALTERNATIVE NEW CONNECT MARKETS ON WARSAW STOCK EXCHANGE
}

\author{
Adjunct professor, Ph.D. Monika Bolek \\ Katedra Rynku i Inwestycji Kapitałowych, Uniwersytet Łódzki \\ ORCID: https://orcid.org/0000-0001-9376-1105 \\ MA Anna Pluskota \\ Katedra Finansów Korporacji, Uniwersytet Łódzki \\ ORCID: https://orcid.org/0000-0002-2566-3420 \\ Assistant Professor, Ph.D. Rafał Wolski \\ Katedra Rynku i Inwestycji Kapitałowych, Uniwersytet Łódzki \\ ORCID: https://orcid.org/0000-0002-4001-2415
}

\begin{abstract}
The goal of this paper is related to the liquidity and profitability relationship analysis and their maxima assessment in the companies listed in the main and alternative markets of Warsaw Stock Exchange. The trade-off between maximum profitability and liquidity is the result of value maximization and bankruptcy prevention strategies and this approach is expected to be similar in all listed companies due to investors' expectation. It has been found that there is no difference in management goals in the markets taken into consideration and companies in both research samples maximize profitability within a conservative approach to the liquidity. The maximum liquidity, on the other hand, is determined with a similar level of profitability as measured by $R O E$ on the main market of WSE and NewConnect.
\end{abstract}

Keywords: liquidity, profitability, trade-off.

JEL Class: G3, M2. 


\section{INTRODUCTION}

The problem of a liquidity-profitability relationship and their trade-off is analyzed in this paper based on the example of two groups of companies listed on the Warsaw Stock Exchange as well as the main and alternative NewConnect markets. In the main market the mature and larger companies are traded while the alternative market is dedicated to the companies in earlier stages of development, and they are significantly smaller. It is assumed that the size is related to the age of company although this relationship does not have to be linear and the maturity is assessed by the market that a company is traded on. The motivation for the presented research is related to some current findings that reflect issues of liquidity and profitability measurement and their maxima, size of companies and types of function describing this phenomena.

According to Louw et al. [2019] different working capital measures are related significantly to different profitability ratios. Dash and Hauman [2009] proposed a goal programming model for optimizing the working capital management. Dalci et al. [2019] investigated whether a firm size influences the relationship between the cash conversion cycle and profitability. Mahmood et al. [2019] evaluated the moderating effects of a firm size and leverage on working capital-profitability relationship, presenting how the break-even point shifts when a company expands. Finally, Adamczyk and Waśniewski [2018] assumed that the liquidity-profitability relation is nonlinear.

The aim of this paper is related to the liquidity-profitability function analysis and the problem presentation in the light of extrema that can help to manage the finances of companies. In the presented paper liquidity is considered in a dynamic and static form, respectively reflected by the cash conversion cycle and current and quick ratios while the profitability is reflected by return on equity and net profit margin. The nonlinear approach is applied for liquidity influencing the profitability and vice versa. Maximum profitability is required in the process of value maximization while maximum liquidity - in the process of regulating obligations and bankruptcy prevention. In young companies, moreover, maximum liquidity can be related to the preparation to the take-off stage, characterized by the fast growth that requires inventories, long terms of payments and cash. The following thesis is verified in this paper: liquidity and profitability have their maxima in relation to each other and they are similar in both sample groups due to investors' expectations.

The paper is composed of several sections: introduction, literature overview, data and methods, results and conclusions. 


\section{LITERATURE OVERVIEW}

The liquidity-profitability relationship is analyzed in the literature taking into account different markets and variety of ratios. Profitability and liquidity directly influence the value of company, whose maximization is a trade-off between maximum earnings and minimum cost of capital related to risk. The trade-off between profitability and liquidity maximization determines the decisions in a company and is the result of their relationship.

The fundamental findings on the liquidity-profitability relationship started the discussion about the ratios that should be taken into consideration and the strategies that make the business successful. Jose et al. [1996] examined the relationship between profitability ratios and liquidity measured by the cash conversion cycle and they found a strong evidence that aggressive working capital policies enhance profitability. Knauer and Wöhrmann [2013] stated that managing current assets and liabilities is highly relevant to the success of the firm. A number of analyses provide evidence of positive effects of accounts receivable and inventory management on profitability. However, the results for the effects of accounts payable management on profitability are driven by reverse causality. Cash conversion cycle was suggested to be the best measure of liquidity e.g. by Richards and Laughlin [1980].

Nazir and Afza [2009] investigated the relationship between working capital management policies and profitability by analyzing the impact of aggressive working capital investment and financing policies on return on assets and Tobin's Q. They concluded that managers can create value if they adopt a conservative approach towards working capital investment and working capital financing policies. The study also proved that investors prefer the stocks of the firms that adopt an aggressive approach to managing their short-term liabilities.

Desai and Joshi [2011] stated that working capital management is an important part in firm's financial management decisions and an optimal working capital should positively influence the creation of a firm value. To reach an optimal working capital level, managers should control the trade-off between profitability and liquidity accurately. Shortening a cash conversion cycle, to a certain level, influences the growth of a company value that is limited by the optimal liquidity. Cash conversion cycle, on the other hand, should be shortened by an aggressive approach to the short-term liabilities rather than conservative receivables and inventories policies. These statements can support value creation in companies listed in the capital markets.

Trade-off reflecting the optimal level of liquidity is a subject of another group of research studies in the field of liquidity-profitability relationship. Eljelly [1991] presented the results of the analysis of the relationship between liquidity and profitability in the context of the optimum of this relation with liquidity being 
measured as a current ratio and the cash conversion cycle. The results showed that there was a negative relationship between liquidity and profitability. On the other hand, Dash and Hauman [2009] proposed a goal programming model for optimizing the working capital management.

The research on the liquidity-profitability is conducted on different markets since the behavior of managers may vary due to the cultural differences. Deloof [2003] was looking for the relation between working capital management and corporate profitability for a sample of large Belgian non-financial firms. The results suggest that managers can increase corporate profitability by reducing a number of days accounts receivable and inventories, therefore decreasing the cash conversion cycle. Lazaridis et al. [2006], on the other hand, investigated the relationship of corporate profitability and working capital management and found statistical significance between profitability measured through gross operating profit, and the cash conversion cycle.

Nobaneee and AlHajjar [2009] investigated the relationship between working capital management and firm profitability on a sample of Japanese non-financial firms listed on the stock exchange. The results suggest that managers can increase profitability of their firms by shortening the cash conversion cycle, the receivables collection period and the inventory conversion period or lengthening the payable deferral period. However, managers should be careful while lengthening the payable deferral period because this could damage the credit reputation and harm profitability in the long run.

The research on the problem of liquidity-profitability was analyzed in groups of companies that represent small firms, too. García-Teruel and Martínez-Solano [2007] provided an empirical evidence on the effects of working capital management on the profitability of a sample of small and medium-sized Spanish firms and found that managers can create value by reducing their inventories and the number of accounts days outstanding. Moreover, shortening the cash conversion cycle also improves the firm's profitability.

Hussain [2012] stated that adequate working capital is essential as it directly affects the profitability and liquidity position of the firm. In order to achieve an optimal level of working capital the managers should accurately control the liquidity-profitability trade-off. The result indicated that low investment in current assets and low current liability financing increases the profitability of firms. The study also suggested that a company size, sale growth and leverage ratio significantly affect the profitability of the firm. The results revealed that profitability of the firm is significantly affected by the working capital management and working management policies.

Dalci et al. [2019] investigated whether a firm size moderates the relationship between the cash conversion cycle and profitability for German non-financial firms. The results show that the relationship between the cash conversion cycle 
and profitability is moderated by a firm size. As the firm size gets smaller and the cash conversion cycle gets longer, the returns on assets decrease. In this context, reducing the length of the cash conversion cycle has a positive impact on profitability for small and medium-sized firms. The size of companies is related to their growth that should be, therefore, linked to the liquidity-profitability relationship. Nastiti et al. [2019] examined the determinants of working capital management and tested different effects of the determinants based on an enterprise size and age. The findings reveal that sales and economic growth determine working capital management. However, the effects of the determinants of working capital management differ depending on an enterprise size and age. To be more specific, economic growth is the only determinant that exhibits different effects on working capital management between different enterprise size and age subsamples. Besides the economic growth, capital expenditure and operating cash flow are the other enterprise-specific determinants that exhibit different effects on working capital management between the two enterprise age subsamples. The empirical results suggest that manufacturing enterprises must focus more on their sales growth because it affects their ability to manage working capital efficiently. Besides, younger manufacturing enterprises need to shorten their cash cycles that are longer compared to old enterprises.

There are numerous techniques used to find the liquidity-profitability relationship and the trade-off between these phenomena starting from a simple cross section analysis through more advanced panel data regressions. Louw et al. [2019] examined and contrasted the long-run relationship between the working capital management and profitability of South African firms. Techniques used in the study included the cointegration and Granger causality tests. The study revealed the long-run relationship between working capital management and the profitability in most of these cases. Further to this, the presence of both unidirectional and bidirectional causality between working capital management and profitability was found. In addition, the results indicated that working capital management had a greater impact on the profitability of retail firms than of construction firms.

Prasad et al. [2019] investigated the impact of deviation from the target investment in working capital measured by a net trade cycle on the profitability measured by gross and net operating income. The authors used a fixed effect regression as the benchmark for finding the determinants of a net trade cycle. Furthermore, this study explored the impact of deviation from the target investments in working capital on the profitability. The results revealed that profitability was influenced by the deviation from the target net trade cycle.

Mahmood et al. [2019] evaluated the moderating effects of a firm size and leverage on the working capital-profitability relationship among Chinese companies. While applying the generalized method of moments technique on 
panel data it was found that a firm size and leverage influenced the working capital-profitability relationship. Small or low-leverage firms have an inverted U-shaped working capital-profitability relationship but this relationship is Ushaped for large or high-leverage firms. This study shows how the break-even point of the working capital-profitability relationship shifts when a company develops.

Vuković and Jakšić [2019] presented a universal approach to the working capital-profitability issue. The research was designed to examine the effect of working capital management on company profitability in the food industry in Southeast Europe. They analyzed the influence of certain variables of working capital management on the probability of higher profitability by applying probit regression. The results showed that most of the analyzed variables of working capital management have a statistically significant impact on the probability of higher profitability.

Adamczyk and Waśniewski [2018] stated that a high liquidity level also causes a decrease in the profitability of the enterprise. They confirmed that excessive liquidity had a negative impact on the profitability, however, the level of liquidity ratios at which this phenomenon occurs, significantly exceeded the values generally considered to be normative, moreover, this study confirmed that liquidity-profitability relationship is nonlinear.

\section{DATA AND METHODS}

The data for the research derives from Notoria Database for the years 2002-2017. The surveys for companies listed on two markets: WSE main and NewConnect alternative markets are analyzed separately. The following sets of yearly variables are used in the study:

- NPM - net profit margin,

- ROE - the return on equity,

- CR - current liquidity ratio,

- QR - quick ratio,

- CCC - cash conversion cycle.

Models with non-linear impact of liquidity on profitability and profitability on liquidity are applied with OLS estimation of panel data. The non-linear relationship is tested using the square function. The general form of the model is presented by an equation:

$$
X_{i, t}=\alpha_{1}+\beta_{1} Y_{i, t}+\beta_{2} Y_{i, t}^{2}+\varepsilon_{i, t}
$$

where $X$ and $Y$ are variables, $\alpha$ is constant, $\beta$ is a model coefficient and $\varepsilon$ is a random component. Certain $\beta$ values allow to determine the maximum function. 


$$
\beta_{1}>0, \beta_{2}<0
$$

For $\beta$ levels (2) it is possible to indicate the maximum values of the quadratic functions. The function given by the formula (1) is used for the analysis of curvilinear dependencies.

In the results presented in the next section, the models will be tested regarding the liquidity-profitability relationships based on the WSE and NewConnect markets.

\section{RESULTS}

Models with non-linear impact of liquidity on profitability and profitability on liquidity are tested in this section. Profitability and liquidity are analyzed as descriptive and described phenomena $(\mathrm{X}, \mathrm{Y})$ because they can influence each other simultaneously in the management process. Maximum profitability is required in the process of value maximization while maximum liquidity can be required in the process regulating obligations and therefore, the bankruptcy prevention. Moreover, its maximum value is necessary in the fast growth stage of development. The research is done in two groups of companies listed on the Warsaw Stock Exchange - mature entities traded in the main market and firms in earlier stages of development traded on $\mathrm{Ne}$ Connect.

\section{WSE MAIN MARKET LISTED COMPANIES}

The WSE main market listed companies analysis is provided in the following section of this paper regarding the non-linear models and their extrema. Models 1,2 and 3 (given by the formulas 3,4 and 5 respectively) with the liquidity influencing profitability measured by $R O E$ are tested and the results are presented in Table 1.

$$
\begin{array}{ll}
\text { Model 1 } & R O E_{i, t}=\alpha_{1}+\beta_{1} C R_{i, t}+\beta_{2} C R_{i, t}^{2}+\varepsilon_{i, t} \\
\text { Model 2 } & R O E_{i, t}=\alpha_{1}+\beta_{1} Q R_{i, t}+\beta_{2} Q R_{i, t}^{2}+\varepsilon_{i, t} \\
\text { Model 3 } & R O E_{i, t}=\alpha_{1}+\beta_{1} C C C_{i, t}+\beta_{2} C C C_{i, t}^{2}+\varepsilon_{i, t}
\end{array}
$$

The parameters of models are presented in Table 1. 
Table 1. Models with non-linear impact of liquidity on profitability (ROE) - WSE main market

\begin{tabular}{|c|c|c|c|}
\hline & $\begin{array}{c}\text { Model 1 } \\
(\mathrm{t}-\text { Student) }\end{array}$ & $\begin{array}{c}\text { Model 2 } \\
\text { (t-Student) }\end{array}$ & $\begin{array}{c}\text { Model 3 } \\
\text { (t-Student) }\end{array}$ \\
\hline Const & $\begin{array}{c}-0.00924501 \\
(-0.8167)\end{array}$ & $\begin{array}{c}0.0628600 \\
(11.26)^{* * *}\end{array}$ & $\begin{array}{c}0.0770953 \\
(16.50)^{* * *}\end{array}$ \\
\hline $\mathrm{CR}$ & $\begin{array}{c}0.0554427 \\
(6.907)^{* * *}\end{array}$ & & \\
\hline $\mathrm{CR}^{\wedge} 2$ & -0.00576719 & & \\
\hline $\mathrm{QR}$ & & 0.00743249 & $(0.9982)$ \\
\hline $\mathrm{QR}^{\wedge} 2$ & & -0.000887061 & 0.0000473933 \\
& & $(-0.8438)$ & $(1.224)$ \\
\hline $\mathrm{CCC}$ & & & -0.000000274445 \\
& & & $(-3.286)^{* * *}$ \\
\hline $\mathrm{CCC}^{\wedge} 2$ & & & 0.004058 \\
\hline Adj. $\mathrm{R}^{\wedge} 2$ & 0.014803 & 0.000285 & 5.785896 \\
& & 0.519836 & $(0.003107)$ \\
\hline F (p value) & 26.73042 & $(0.594662)$ & -76.35745 \\
\hline Akaike criterion & 367.1792 & 504.0717 & 0.798044 \\
\hline Durbin-Watson Stat. & 0.832233 & 0.815877 & no \\
\hline Extremum & 4.8 & no & \\
\hline
\end{tabular}

It is assumed that the parameter is statistically significant for every p-value smaller than 0.1 , for increasing confidence intervals of $1 \%(* * *), 5 \%(* *)$ and $10 \%(*)$ respectively. The models are characterized by low $\mathrm{R}$ square values because their purpose is not to explain the phenomena. The $\mathrm{p}$ value for the $\mathrm{F}$ statistic below 0.05 means that the model consists of variables that have a statistically significant impact on the explained variable. The Akaike criterion allows to compare models with each other. The Durbin-Watson statistics indicate autocorrelation of model residuals, and its value is characteristic for models based on financial data.

Source: own calculations.

Based on the results presented in Table 1 it can be concluded that in Model 1 the non-linear effect of current ratio on $R O E$ is found with the level of 4.8. In the case of Models 2 and 3 no non-linear relationship between liquidity and profitability is found and the maxima of the functions are not determined.

Table 2 contains results for non-linear models representing the impact of liquidity on net profit margin given by Models 4, 5 and 6 (formulas 6, 7 and 8 respectively).

$$
\begin{array}{ll}
\text { Model 4 } & N P M_{i, t}=\alpha_{1}+\beta_{1} C R_{i, t}+\beta_{2} C R_{i, t}^{2}+\varepsilon_{i, t} \\
\text { Model 5 } & N P M_{i, t}=\alpha_{1}+\beta_{1} Q R_{i, t}+\beta_{2} Q R_{i, t}^{2}+\varepsilon_{i, t} \\
\text { Model 6 } & N P M_{i, t}=\alpha_{1}+\beta_{1} C C C_{i, t}+\beta_{2} C C C_{i, t}^{2}+\varepsilon_{i, t}
\end{array}
$$


The results of models estimation are presented in Table 2 .

Table 2. Models with a non-linear effect of liquidity on the net profit margin - WSE main market

\begin{tabular}{|c|c|c|c|}
\hline & $\begin{array}{c}\text { Model } 4 \\
\text { (t-Student) }\end{array}$ & $\begin{array}{c}\text { Model 5 } \\
\text { (t-Student) }\end{array}$ & $\begin{array}{c}\text { Model } 6 \\
\text { (t-Student) }\end{array}$ \\
\hline Const & $\begin{array}{l}-0.0675641 \\
(-5.417)^{* * *}\end{array}$ & $\begin{array}{l}0.0167377 \\
(2.697) * * *\end{array}$ & $\begin{array}{l}0.0371407 \\
(9.150) * * *\end{array}$ \\
\hline $\mathrm{CR}$ & $\begin{array}{l}0.0712258 \\
(7.925) * * *\end{array}$ & & \\
\hline $\mathrm{CR}^{\wedge} 2$ & $\begin{array}{l}-0.00531375 \\
(-4.681)^{* * *} \\
\end{array}$ & & \\
\hline QR & & $\begin{array}{l}0.0524345 \\
(5.975)^{* * *}\end{array}$ & \\
\hline $\mathrm{QR}^{\wedge} 2$ & & $\begin{array}{c}-0.00336992 \\
(-2.636) * * *\end{array}$ & \\
\hline $\mathrm{CCC}$ & & & $\begin{array}{c}0.000198477 \\
(5.913) * * * \\
\end{array}$ \\
\hline $\mathrm{CCC}^{\wedge} 2$ & & & $\begin{array}{c}-0.000000787958 \\
(-1.054)^{* * *}\end{array}$ \\
\hline Adj. R7.^2 & 0.038526 & 0.024540 & 0.012426 \\
\hline $\mathrm{F}$ (p value) & $\begin{array}{l}69.50163 \\
(0.0000)\end{array}$ & $\begin{array}{l}44.39046 \\
(0.0000)\end{array}$ & $\begin{array}{l}18.16242 \\
(0.0000)\end{array}$ \\
\hline Akaike criterion & 975.77 & 1194.49 & -844.95 \\
\hline Durbin-Watson Stat. & 1.037085 & 1.041332 & 0.973024 \\
\hline Extremum & 6.7 & 7.78 & 125.94 \\
\hline
\end{tabular}

It is assumed that the parameter is statistically significant for every p-value smaller than 0.1 , for increasing confidence intervals of $1 \%(* * *), 5 \%(* *)$ and $10 \%(*)$ respectively. The models are characterized by low $\mathrm{R}$ square values because their purpose is not to explain the phenomena. The $\mathrm{p}$ value for the F statistic below 0.05 means that the model consists of variables that have a statistically significant impact on the explained variable. The Akaike criterion allows to compare models with each other. The Durbin-Watson statistics indicate autocorrelation of model residuals, and its value is characteristic for models based on financial data.

Source: own calculations.

Table 2 contains the results of estimation the parameters of the models with non-linear function of liquidity affecting net profit margin and it can be concluded that they are significant in all three cases. The maximum of net profit margin level is when current ratio is 6.7, quick ratio 7.78 and cash conversion cycle 125.94 days.

Since profitability can influence liquidity in the bankruptcy prevention process, Table 3 presents the results of non-linear functions estimation with ROE influencing the liquidity given by the Models 7, 8 and 9 (formulas 9, 10 and 11 respectively). 
Model 7

$$
\begin{array}{ll}
\text { Model } 7 & C R_{i, t}=\alpha_{1}+\beta_{1} R O E_{i, t}+\beta_{2} R O E_{i, t}^{2}+\varepsilon_{i, t} \\
\text { Model } 8 & Q R_{i, t}=\alpha_{1}+\beta_{1} R O E_{i, t}+\beta_{2} R O E_{i, t}^{2}+\varepsilon_{i, t}
\end{array}
$$$$
\text { Model } 9 \quad C C C_{i, t}=\alpha_{1}+\beta_{1} R O E_{i, t}+\beta_{2} R O E_{i, t}^{2}+\varepsilon_{i, t}
$$

The results of models estimation are presented in Table 3.

Table 3. Models with non-linear impact of profitability on liquidity - WSE main market

\begin{tabular}{|c|c|c|c|}
\hline & $\begin{array}{c}\text { Model 7 } \\
\text { CR } \\
\text { (t-Student) }\end{array}$ & $\begin{array}{c}\text { Model 8 } \\
\text { QR } \\
\text { (t-Student) }\end{array}$ & $\begin{array}{c}\text { Model 9 } \\
\text { CCC } \\
\text { (t-Student) }\end{array}$ \\
\hline Const. & $\begin{array}{c}2.14105 \\
(69.16)^{* * *}\end{array}$ & $\begin{array}{c}0.844000 \\
(30.51)^{* * *}\end{array}$ & $\begin{array}{c}21.9832 \\
(9.036)^{* * *}\end{array}$ \\
\hline ROE & $\begin{array}{c}0.380916 \\
(3.287)^{* * *}\end{array}$ & $\begin{array}{c}0.0391770 \\
(0.3832)\end{array}$ & $\begin{array}{c}2.30645 \\
(0.2414)\end{array}$ \\
\hline ROE^2 & -0.319823 & -0.0521552 & -20.2160 \\
& $(-2.651)^{* * *}$ & $(-0.4958)$ & 0.001686 \\
\hline Adj. R^2 & 0.007489 & 0.000157 & 2.397791 \\
\hline F (p value) & 13.42323 & 0.286758 & $(0.091103)$ \\
\hline Akaike criterion & $10.0000)$ & $(0.750710)$ & 35110.56 \\
\hline Durbin-Watson Stat. & 0.669225 & 13370.88 & 0.643530 \\
\hline Extremum & 0.59 & 0.764911 & no \\
\hline
\end{tabular}

It is assumed that the parameter is statistically significant for every p-value smaller than 0.1 , for increasing confidence intervals of $1 \%(* * *), 5 \%(* *)$ and $10 \%(*)$ respectively. The models are characterized by low $\mathrm{R}$ square values because their purpose is not to explain the phenomena. The $\mathrm{p}$ value for the $\mathrm{F}$ statistic below 0.05 means that the model consists of variables that have a statistically significant impact on the explained variable. The Akaike criterion allows to compare models with each other. The Durbin-Watson statistics indicate autocorrelation of model residuals, and its value is characteristic for models based on financial data.

Source: own calculations.

As it is presented in Table 3, a significant statistical impact of ROE on current ratio was found with the maximum value 0.59 , in the other models no extremum was found.

Table 4 contains the results of non-linear models estimation regarding the impact of net profit margins on liquidity for the WSE main market given by Models 10, 11 and 12 (formulas 12, 13 and 14 respectively).

$$
\begin{array}{ll}
\text { Model 10 } & C R_{i, t}=\alpha_{1}+\beta_{1} N P M_{i, t}+\beta_{2} N P M_{i, t}^{2}+\varepsilon_{i, t} \\
\text { Model 11 } & Q R_{i, t}=\alpha_{1}+\beta_{1} N P M_{i, t}+\beta_{2} N P M_{i, t}^{2}+\varepsilon_{i, t} \\
\text { Model 12 } & C C C_{i, t}=\alpha_{1}+\beta_{1} N P M_{i, t}+\beta_{2} N P M_{i, t}^{2}+\varepsilon_{i, t}
\end{array}
$$


The results of models estimation are presented in Table 4 .

Table 4. Models with non-linear impact of net profit margin on liquidity - WSE main market

\begin{tabular}{|c|c|c|c|}
\hline & $\begin{array}{c}\text { Model 10 } \\
\text { CR } \\
\text { (t-Student) }\end{array}$ & $\begin{array}{c}\text { Model 11 } \\
\text { QR } \\
\text { (t-Student) }\end{array}$ & $\begin{array}{c}\text { Model 12 } \\
\text { CCC } \\
(\mathrm{t}-\text { Student) }\end{array}$ \\
\hline Const. & 1.99927 & 0.657474 & 13.7923 \\
& $(70.83)^{* * *}$ & $(27.52)^{* * *}$ & $(6.181)^{* * *}$ \\
\hline NPM & 1.10886 & 0.783397 & 60.7831 \\
& $(11.57)^{* * *}$ & $(9.920)^{* * *}$ & $(5.926)^{* * *}$ \\
\hline NPM`2 $^{\wedge}$ & 0.523678 & 0.762486 & 2.52388 \\
& $(6.600)^{* * *}$ & $(11.72)^{* * *}$ & $(0.2653)$ \\
\hline Adj. $\mathrm{R}^{\wedge} 2$ & 0.044451 & 0.059261 & 0.012070 \\
\hline F (p value) & 80.68721 & 111.1534 & 17.63614 \\
& $(0.0000)$ & $(0.0000)$ & $(0.0000)$ \\
\hline Akaike criterion & 13082.20 & 12187.26 & 35638.72 \\
\hline Durbin-Watson Stat. & 0.671896 & 0.815457 & 0.608264 \\
\hline Extremum & no & no & no \\
\hline
\end{tabular}

It is assumed that the parameter is statistically significant for every p-value smaller than 0.1 , for increasing confidence intervals of $1 \%(* * *), 5 \%(* *)$ and $10 \%(*)$ respectively. The models are characterized by low $\mathrm{R}$ square values because their purpose is not to explain the phenomena. The $\mathrm{p}$ value for the $\mathrm{F}$ statistic below 0.05 means that the model consists of variables that have a statistically significant impact on the explained variable. The Akaike criterion allows to compare models with each other. The Durbin-Watson statistics indicate autocorrelation of model residuals, and its value is characteristic for models based on financial data.

Source: own calculations.

As it is presented in Table 4, Models 10 and 11 show a non-linear influence of net profit margin on liquidity, but without an extreme value. For Model 12 no non-linear relationship was found.

\section{NEWCONNECT ALTERNATIVE MARKET LISTED COMPANIES}

Models 13, 14 and 15 (formulas 15, 16 and 17 respectively) representing the influence of liquidity on profitability measured by $R O E$ on the New Connect alternative market are tested and the results are presented in Table 5.

$$
\begin{array}{ll}
\text { Model 13 } & R O E_{i, t}=\alpha_{1}+\beta_{1} C R_{i, t}+\beta_{2} C R_{i, t}^{2}+\varepsilon_{i, t} \\
\text { Model 14 } & R O E_{i, t}=\alpha_{1}+\beta_{1} Q R_{i, t}+\beta_{2} Q R_{i, t}^{2}+\varepsilon_{i, t} \\
\text { Model 15 } & R O E_{i, t}=\alpha_{1}+\beta_{1} C C C_{i, t}+\beta_{2} C C C_{i, t}^{2}+\varepsilon_{i, t}
\end{array}
$$

The results of models parameters estimation are presented in Table 5. 
Table 5. Models with non-linear impact of liquidity on profitability $(R O E)$ - New Connect alternative market

\begin{tabular}{|c|c|c|c|}
\hline & $\begin{array}{l}\text { Model } 13 \\
\text { (t-Student) }\end{array}$ & $\begin{array}{l}\text { Model 14 } \\
\text { (t-Student) }\end{array}$ & $\begin{array}{l}\text { Model } 15 \\
\text { (t-Student) }\end{array}$ \\
\hline Const. & $\begin{array}{c}-0.183619 \\
(-8.079)^{* * *}\end{array}$ & $\begin{array}{l}-0.0308814 \\
(-2.519)^{* * *}\end{array}$ & $\begin{array}{l}0.0370466 \\
(2.539)^{* *}\end{array}$ \\
\hline $\mathrm{CR}$ & $\begin{array}{l}0.123410 \\
(8.364) * * *\end{array}$ & & \\
\hline $\mathrm{CR}^{\wedge} 2$ & $\begin{array}{l}-0.0122999 \\
(-7.243)^{* * *}\end{array}$ & & \\
\hline QR & & $\begin{array}{l}0.0560228 \\
(4.196) * * *\end{array}$ & \\
\hline $\mathrm{QR}^{\wedge} 2$ & & $\begin{array}{l}-0.00683428 \\
(-3.916)^{* * *}\end{array}$ & \\
\hline $\mathrm{CCC}$ & & & $\begin{array}{c}-0.0000895577 \\
(-0.8163)\end{array}$ \\
\hline $\mathrm{CCC}^{\wedge} 2$ & & & $\begin{array}{c}-0.000000217719 \\
(-1.679)^{*}\end{array}$ \\
\hline Adj. $R^{\wedge} 2$ & 0.036867 & 0.008336 & 0.009782 \\
\hline $\mathrm{F}$ (p value) & $\begin{array}{l}37.91405 \\
(0.0000) \\
\end{array}$ & $\begin{array}{c}8.805705 \\
(0.000155) \\
\end{array}$ & $\begin{array}{c}4.139155 \\
(0.016263) \\
\end{array}$ \\
\hline Akaike criterion & 2107.434 & 2222.499 & 881.9031 \\
\hline Durbin-Watson Stat. & 0.915441 & 0.889268 & 1.041390 \\
\hline Extremum & 5.02 & 4.10 & no \\
\hline
\end{tabular}

It is assumed that the parameter is statistically significant for every p-value smaller than 0.1 , for increasing confidence intervals of $1 \%(* * *), 5 \%(* *)$ and $10 \%(*)$ respectively. The models are characterized by low $\mathrm{R}$ square values because their purpose is not to explain the phenomena. The $\mathrm{p}$ value for the $\mathrm{F}$ statistic below 0.05 means that the model consists of variables that have a statistically significant impact on the explained variable. The Akaike criterion allows to compare models with each other. The Durbin-Watson statistics indicate autocorrelation of model residuals, and its value is characteristic for models based on financial data.

Source: own calculations.

Models 13 and 14 estimation, as it is presented in Table 5, confirm the non-linear impact of current and quick ratios on ROE. The maximum value of function for current ratio is 5.02, while for quick ratio it is 4.1.

Table 6 contains results of estimation of models with a non-linear effect of liquidity on the net profit margin. Models 16, 17 and 18 (formulas 18, 19 and 20 respectively) present this relationship.

$$
\begin{array}{ll}
\text { Model } 16 & N P M_{i, t}=\alpha_{1}+\beta_{1} C R_{i, t}+\beta_{2} C R_{i, t}^{2}+\varepsilon_{i, t} \\
\text { Model } 17 & N P M_{i, t}=\alpha_{1}+\beta_{1} Q R_{i, t}+\beta_{2} Q R_{i, t}^{2}+\varepsilon_{i, t} \\
\text { Model 18 } & N P M_{i, t}=\alpha_{1}+\beta_{1} C C C_{i, t}+\beta_{2} C C C_{i, t}^{2}+\varepsilon_{i, t}
\end{array}
$$


The results of models parameters estimation are presented in Table 6.

Table 6. Models with a non-linear effect of liquidity on the net profit margin - NewConnect alternative market

\begin{tabular}{|c|c|c|c|}
\hline & $\begin{array}{l}\text { Model } 16 \\
\text { (t-Student) }\end{array}$ & $\begin{array}{l}\text { Model } 17 \\
\text { (t-Student) }\end{array}$ & $\begin{array}{l}\text { Model } 18 \\
\text { (t-Student) }\end{array}$ \\
\hline Const & $\begin{array}{l}-0.218954 \\
(-9.852) * * *\end{array}$ & $\begin{array}{l}-0.0787423 \\
(-6.618) * * *\end{array}$ & $\begin{array}{c}-0.0159687 \\
(-1.520)\end{array}$ \\
\hline $\mathrm{CR}$ & $\begin{array}{c}0.123160 \\
(8.302)^{* * *}\end{array}$ & & \\
\hline $\mathrm{CR}^{\wedge} 2$ & $\begin{array}{l}-0.0123552 \\
(-7.100)^{* * *}\end{array}$ & & \\
\hline$\overline{\mathrm{QR}}$ & & $\begin{array}{l}0.0624816 \\
(4.514) * * *\end{array}$ & \\
\hline $\mathrm{QR}^{\wedge} 2$ & & $\begin{array}{l}-0.00633275 \\
(-3.423)^{* * *}\end{array}$ & \\
\hline $\mathrm{CCC}$ & & & $\begin{array}{c}-0.000190721 \\
(-2.405)^{* *}\end{array}$ \\
\hline $\mathrm{CCC}^{\wedge} 2$ & & & $\begin{array}{c}-0.00000009 .58273 \\
(-0.7509)\end{array}$ \\
\hline Adj. $R^{\wedge} 2$ & 0.038599 & 0.012640 & 0.011328 \\
\hline $\mathrm{F}$ (p value) & $\begin{array}{l}37.88005 \\
(0.0000)\end{array}$ & $\begin{array}{l}12.74445 \\
(0.0000)\end{array}$ & $\begin{array}{c}4.938175 \\
(0.007372)\end{array}$ \\
\hline Akaike criterion & 1870.637 & 1977.301 & 364.7186 \\
\hline Durbin-Watson Stat. & 0.998390 & 0.980778 & 0.862567 \\
\hline Extremum & 5.5 & 4.93 & no \\
\hline
\end{tabular}

It is assumed that the parameter is statistically significant for every p-value smaller than 0.1 , for increasing confidence intervals of $1 \%(* * *), 5 \%(* *)$ and $10 \%(*)$ respectively. The models are characterized by low $\mathrm{R}$ square values because their purpose is not to explain the phenomena. The $\mathrm{p}$ value for the F statistic below 0.05 means that the model consists of variables that have a statistically significant impact on the explained variable. The Akaike criterion allows to compare models with each other. The Durbin-Watson statistics indicate autocorrelation of model residuals, and its value is characteristic for models based on financial data.

Source: own calculations.

As it is presented in Table 6 the maximum value of function for Model 16 is 0.5 for current ratio, while the maximum value for Model 17 is 4.93 for quick ratio.

The results of estimation models representing the impact of profitability on liquidity are presented in Table 7 regarding Models 19, 20 and 21 (formulas 21, 22 and 23 respectively). 
$\begin{array}{ll}\text { Model 19 } & C R_{i, t}=\alpha_{1}+\beta_{1} R O E_{i, t}+\beta_{2} R O E_{i, t}^{2}+\varepsilon_{i, t} \\ \text { Model 20 } & Q R_{i, t}=\alpha_{1}+\beta_{1} R O E_{i, t}+\beta_{2} R O E_{i, t}^{2}+\varepsilon_{i, t} \\ \text { Model 21 } & C C C_{i, t}=\alpha_{1}+\beta_{1} R O E_{i, t}+\beta_{2} R O E_{i, t}^{2}+\varepsilon_{i, t}\end{array}$

The results of models parameters estimation are presented in Table 7.

Table 7. Models with non-linear impact of profitability on liquidity

- NewConnect alternative market

\begin{tabular}{|c|c|c|c|}
\hline & $\begin{array}{c}\text { Model 19 } \\
\text { CR }\end{array}$ & $\begin{array}{c}\text { Model 20 } \\
\text { QR }\end{array}$ & $\begin{array}{c}\text { Model 21 } \\
\text { CCC }\end{array}$ \\
\hline Const & 2.58462 & 1.28828 & 49.9672 \\
& $(51.18)^{* * *}$ & $(27.60)^{* * *}$ & $(8.054)^{* * *}$ \\
\hline ROE & 0.368352 & 0.00988544 & -48.4011 \\
& $(2.864)^{* * *}$ & $(0.08323)$ & $(-3.015)^{* *}$ \\
\hline ROE$^{\wedge}$ & -0.282710 & -0.277187 & -28.5110 \\
& $(-2.426)^{* *}$ & $(-2.549)^{* *}$ & $(-1.948)^{*}$ \\
\hline Adj. R^2 & 0.014291 & 0.004165 & 0.010931 \\
\hline F (p value) & 14.36050 & 4.381596 & 4.630505 \\
& $(0.0000)$ & $(0.012620)$ & $(0.010001)$ \\
\hline Akaike criterion & 8502.541 & 8784.247 & 10944.48 \\
\hline Durbin-Watson Stat. & 0.998390 & 0.908871 & 0.741456 \\
\hline Extremum & 0.65 & no & no \\
\hline
\end{tabular}

It is assumed that the parameter is statistically significant for every p-value smaller than 0.1 , for increasing confidence intervals of $1 \%(* * *), 5 \%(* *)$ and $10 \%(*)$ respectively. The models are characterized by low $\mathrm{R}$ square values because their purpose is not to explain the phenomena. The $\mathrm{p}$ value for the $\mathrm{F}$ statistic below 0.05 means that the model consists of variables that have a statistically significant impact on the explained variable. The Akaike criterion allows to compare models with each other. The Durbin-Watson statistics indicate autocorrelation of model residuals, and its value is characteristic for models based on financial data.

Source: own calculations.

Based on the results presented in Table 7 the non-linear impact of ROE on current ratio and cash conversion cycle can be confirmed. However, the maximum function can only be determined for model 19 with current ratio as an endogenic variable with the value of $R O E 0.65$.

Table 8 contains estimation of non-linear models related to the impact of net profit margin on liquidity and are presented in Models 22, 23 and 24 (formulas 24, 25 and 26 respectively). 
Model 22

$$
\begin{aligned}
& C R_{i, t}=\alpha_{1}+\beta_{1} N P M_{i, t}+\beta_{2} N P M_{i, t}^{2}+\varepsilon_{i, t} \\
& Q R_{i, t}=\alpha_{1}+\beta_{1} N P M_{i, t}+\beta_{2} N P M_{i, t}^{2}+\varepsilon_{i, t} \\
& C C C_{i, t}=\alpha_{1}+\beta_{1} N P M_{i, t}+\beta_{2} N P M_{i, t}^{2}+\varepsilon_{i, t}
\end{aligned}
$$

Model 23$$
\text { Model } 24
$$

The results of models parameters estimation are presented in Table 8.

Table 8 . Models with non-linear impact of net profit margin on liquidity - New Connect alternative market

\begin{tabular}{|c|c|c|c|}
\hline & $\begin{array}{c}\text { Model 22 } \\
\text { CR }\end{array}$ & $\begin{array}{c}\text { Model 23 } \\
\text { QR }\end{array}$ & $\begin{array}{c}\text { Model 24 } \\
\text { CCC }\end{array}$ \\
\hline Const & 2.41135 & 1.06686 & 30.5341 \\
& $(50.16)^{* * *}$ & $(25.11)^{* * *}$ & $(6.121)^{* * *}$ \\
\hline NPM & 0.731954 & 0.561597 & -60.9831 \\
& $(5.615)^{* * *}$ & $(4.812)^{* * *}$ & $(-2.527)^{* *}$ \\
\hline $\mathrm{NPM}^{\wedge} 2$ & 0.262332 & 0.291355 & -11.7844 \\
& $(2.606)^{* * *}$ & $(3.207)^{* * *}$ & $(-0.6559)$ \\
\hline Adj. R^2 & 0.016456 & 0.011934 & 0.011175 \\
\hline F (p value) & 15.78601 & 12.02394 & 4.870668 \\
& $(0.0000)$ & $(0.0000)$ & $(0.007881)$ \\
\hline Akaike criterion & 7967.968 & 8020.940 & 11031.51 \\
\hline Durbin-Watson Stat. & 0.934969 & 0.944633 & 0.539787 \\
\hline Extremum & no & no & no \\
\hline
\end{tabular}

It is assumed that the parameter is statistically significant for every p-value smaller than 0.1 , for increasing confidence intervals of $1 \%(* * *), 5 \%(* *)$ and $10 \%(*)$ respectively. The models are characterized by low $\mathrm{R}$ square values because their purpose is not to explain the phenomena. The $\mathrm{p}$ value for the $\mathrm{F}$ statistic below 0.05 means that the model consists of variables that have a statistically significant impact on the explained variable. The Akaike criterion allows to compare models with each other. The Durbin-Watson statistics indicate autocorrelation of model residuals, and its value is characteristic for models based on financial data.

Source: own calculations.

Table 8 contains the results of estimation of non-linear models for the impact of net profit margin on liquidity and it can be concluded that these models show a non-linear relationship, but without extrema.

The maximum values for ratios representing the liquidity and profitability in the two research groups containing companies traded on main and alternative markets of Warsaw Stock Exchange were analyzed. The pattern of results shows that the conservative approach to the liquidity results in the profitability maximization both for ROE and NPM similarly on both markets are taken into consideration. Profitability influences the liquidity in a lower degree in both subsamples and it is slightly lower for the companies traded on the main WSE market than on NewConnect if companies focus on maximum liquidity. 


\section{CONCLUSIONS}

The problem of maximum levels of different ratios representing the working capital management strategies was analyzed in two groups of companies: larger and smaller ones traded respectively on the main and alternative markets of the Warsaw Stock Exchange. Moreover based on the assumption that the liquidityprofitability relationship is not-linear, in the presented research the square function was applied.

The value maximization and liquidity maintenance are the main goals of the company performance when the financial aspects are taken into consideration. Liquidity influences the profitability as well as profitability can influence liquidity in the process of management. In the case of liquidity affecting the profitability, the value creation is the main purpose of management and in case of profitability affecting the liquidity the ability to regulate obligations, operating risk reduction and finally bankruptcy prevention are the main issues. In young companies maximum level of liquidity can be related to the fast growth. For this reason models are tested both for liquidity affecting the profitability and profitability affecting the liquidity.

The results show the similar patterns of management in the two research groups. Maximum profitability measured by $R O E$ for the main market is 4.8 and for New Connect market 5.02. as measured by current ratio. The liquidity is slightly lower for mature companies than for smaller ones, but in each case the conservative approach generates the maximum profitability. In case of NewConnect the quick ratio also influences $R O E$. In case of net profit margin, the current ratio influences it in both markets and the liquidity as measured by current ratio is lower for alternative market in relation to the maximum level of NPM. In case of larger companies cash conversion cycle significantly determines for instance the maximum level of net profit margin.

When the opposite relationship is taken into consideration and profitability influences the liquidity, on both analyzed markets $R O E$ is related to the maximum level of current ratio.

It can be concluded that companies traded on main and alternative markets of WSE are managed in a similar way, the conservative liquidity approach is related to the maximum values of profitability and $R O E$ also determines the maximum level of current ratio in both markets.

It must be stated that the presented results should be taken into account with some caution. First of all, the authors are aware of the weakness of available data and proposed models. Although the data includes time series of 15 years, it seems that the period is too short for this type of study. This limitation, however, is insurmountable and is mainly due to the length of functioning of the NewConnect alternative market. It is worth adding that there were often gaps in the observations 
caused by the company's withdrawal from the stock exchange or suspension of its listing. Unfortunately, this is quite a characteristic feature of the young NewConnect market. The models themselves are characterized by a very low $\mathrm{R}$ square, but the $\mathrm{F}$ statistics in the analyzed cases are significant, and the determination of maxima and minima alone does not require particularly well-chosen models. The authors believe that further research can help to confirm their conclusions by comparing other markets.

\section{BIBLIOGRAPHY}

Adamczyk A., Waśniewski P., 2018, Czy istnieje nadpłynność? Analiza związu między plynnościa a rentownościa, „Finanse, Rynki Finansowe, Ubezpieczenia”, nr 92.

Dalci I., Tanova C., Ozyapici H., Bein M.A., 2019, The Moderating Impact of Firm Size on the Relationship between Working Capital Management and Profitability, „Prague Economic Papers", vol. 3.

Dash M., Hanuman R., 2009, A Liquidity-Profitability Trade-Off Model for Working Capital Management, „SSRN Working Paper Series”, no. 10, http://ssrn.com/abstract=1408722, [dostęp 30.09.2020].

Deloof M., 2003, Does Working Capital Management Affect Profitability of Belgian Firms?, „Journal of Business Finance \& Accounting”, vol. 30, issue 3-4, doi: 10.1111/14685957.00008.

Desai J., Joshi N., 2011, Effect of Working Capital Management on Profitability of Firms in India, „SSRN Working Paper Series”, http://ssrn.com/abstract=1774686 [dostęp 30.09.2020].

Eljelly A., 1991, Liquidity-profitability tradeoff: An empirical investigation in an emerging market, „International Journal of Commerce and Management”, vol. 14(2), doi: $10.1108 / 10569210480000179$.

García-Teruel P.J., Martínez-Solano P., 2007, Effects of working capital management on SME profitability, „International Journal of Managerial Finance”, vol. 3, issue 2.

Hussain A., 2012, Aggressiveness and conservativeness of working capital: A case of Pakistani manufacturing sector, „European Journal Of Scientific Research”, vol. 73, issue 2.

Jose M.L., Lancaster C., Stevens J.L., 1996, Corporate Returns and Cash Conversion Cycles, „Journal of Economics and Finance”, vol. 20, no. 1.

Knauer T., Wöhrmann A., 2013, Working capital management and firm profitability, „Journal of Management Control", vol. 24, issue 1.

Lazaridis I., Tryfonidis D., 2006, Relationship Between Working Capital Management And Profitability Of Listed Companies In The Athens Stock Exchange, „Journal of Financial Management \& Analysis", Jan-Jun, vol. 19, issue 1.

Louw E., Hall J.H., Pradhan R.P., 2019, The Relationship Between Working Capital Management and Profitability: Evidence from South African Retail and Construction Firms, „Global Business Review", vol. 12, doi: 0972150919865104.

Mahmood F., Han D., Ali N., Mubeen R., Shahza U., 2019, Moderating Effects of Firm Size and Leverage on the Working Capital Finance-Profitability Relationship: Evidence from China, ,Sustainability”, vol. 11(7).

Nastiti P.K.Y., Atahau A.D.R., Supramono S., 2019, Working capital management and its influence on profitability and sustainable growth, „Business: Theory and Practice”, no. 20.

Nazir Mian Sajid, Afza Talat, 2009, Impact of Aggressive Working Capital Management Policy on Firms' Profitability, „IUP Journal of Applied Finance”, vol. 15, issue 8. 
Nobaneee H., AlHajjar M., 2009, A note on Working Capital Management and Corporate Profitability of Japanese Firms, „SSRN Working Paper Series”, no. 9, http://ssrn.com/abstract=1433243 [dostęp 30.09.2020].

Prasad P., Sivasankaran N., Shukla A., 2019, Impact of deviation from target working capital on firm profitability: Evidence from India, ,International Journal of Productivity and Performance Management", vol. 68(1).

Richards V.D., Laughlin E.J., 1980, A cash conversion cycle approach to liquidity analysis, „Financial Management”, vol. 9.

Vuković B., Jakšić D., 2019, The effect of working capital management on profitability: Evidence from southeast europe, „Ekonomika poljoprivrede”, vol. 66(1). 